\title{
KAUSALITAS ANTARA FUNDAMENTAL EKONOMI DAERAH DAN PERAN WANITA DALAM PEMBANGUNAN
}

\author{
Amin Pujiati \\ Fakultas Ekonomi Universitas Negeri Semarang \\ Gedung C3 Lantai 1 Kampus Sekaran Gunungpati Semarang 50229 \\ E-mail: apuji06@yahoo.co.id
}

Diterima 10 September 2011 / Disetujui 15 April 2012

\begin{abstract}
This study aims to analyze the role of women in development and the causality between regional economic fundamentals and the role of women at Central Java. It uses district level data and supplied by the Indonesian Central Bureau of Statistics during 2001- 2009. The tools of analysis Granger Causality Test. The results of the analysis of the role of women in development is still low, from education, health, women's role and potential of public sector point of view. The Granger Causality tests results shows that a direct relationship between women's role in regional development with economic fundamentals, that also the role of women in development increased, causing increased local economic fundamentals. In this study there is no reciprocal relationship between economic fundamentals and the role of women.
\end{abstract}

Keywords: regional economic fundamentals, the role of women, development, granger causality

\begin{abstract}
Abstrak: Studi ini bertujuan untuk menganalisis peran wanita dalam pembangunan serta menguji hubungan kausalitas antara fundamental ekonomi daerah dan peran wanita dalam pembangunan. Data yang digunakan adalah data sekunder yang bersumber dari Biro Pusat Statistik selama periode 2001-2009. Alat analisis menggunakan Uji Kausalitas Granger. Hasil studi menunjukkan peran wanita dalam pembangunan masih rendah, dilihat dari aspek pendidikan, kesehatan dan peran wanita di sektor publik. Hasil uji Kausalitas Granger menunjukkan terdapat hubungan searah antara peran wanita dalam pembangunan dan fundamental ekonomi, bukan hubungan yang timbal balik. Hal ini berarti peran wanita dalam pembangunan yang meningkat, menyebabkan fundamental ekonomi daerah meningkat.
\end{abstract}

Kata kunci: fundamental ekonomi daerah, peran wanita, pembangunan, kausalitas granger

\section{PENDAHULUAN}

Menurut Todaro (2006) pembangunan multidimensional suatu daerah haruslah mencakup tiga inti nilai pertama, ketahanan (sustenance) yaitu kemampuan untuk memenuhi kebutuhan pokok (sandang, pangan, papan, kesehatan, dan proteksi) untuk mempertahankan hidup. Kedua, harga diri (self esteem) yaitu pembangunan haruslah memanusiakan orang. Pembangunan suatu daerah dalam arti luas haruslah meningkatkan kebanggaan sebagai manusia yang berada di daerah itu. Ketiga, kebebasan (freedom from servitude) yaitu kebebasan bagi setiap individu suatu negara untuk berpikir, berkembang, berperilaku, dan berusaha untuk berpartisipasi dalam pembangunan. Dengan kata lain, pembangunan ekonomi tidak lagi memuja Produk Domestik Regional Bruto, namun lebih memusatkan perhatian pada kualitas dari proses pembangunan.

Sasaran pembangunan bukan "kue daerah" dan "pertumbuhan kue" namun pembangunan manusianya. Pembangunan berarti tidak ada lagi masalah kemiskinan, pengangguran serta ketimpangan, jika masih ada masalah- 
masalah tersebut maka sulit dikatakan sudah ada pembangunan. Capaian hasil pembangunan perlu indikator fundamental ekonomi daerah (Kuncoro, 2004). Indikator fundamental ekonomi daerah yang dimaksud meliputi pertumbuhan ekonomi dan pendapatan perkapita daerah, indikator pembangunan manusia $(\mathrm{Hu}-$ man Development Index/HDI). Pertumbuhan ekonomi yang tinggi tetapi tidak diimbangi dengan pembangunan manusia yang tinggi pula tidak akan berarti capaian hasil pembangunan. Hal ini disebabkan sasaran pembangunan adalah pembangunan manusia. HDI mengukur capaian pembangunan manusia berdasarkan sejumlah komponen dasar kualitas hidup yaitu capaian umur panjang dan sehat (angka harapan hidup), angka melek huruf dan rata-rata lama sekolah serta kemampuan daya beli terhadap kebutuhan pokok yang dilihat dari ratarata besarnya pengeluaran per kapita sebagai pendapatan.

Salah satu hal penting yang mempengaruhi HDI adalah kualitas hidup perempuan. Apabila kualitas hidup perempuan rendah maka indeks pembangunan manusia juga rendah dan keberhasilan pembangunan rendah. Pembangunan pemberdayaan perempuan merupakan salah satu prioritas pembangunan. Kualitas hidup dan partisipasi perempuan dalam pembangunan, terutama di bidang pendidikan, kesehatan, ekonomi dan politik, masih rendah, di samping masih adanya berbagai bentuk praktek diskriminasi dan eksploitasi. Disadari sudah banyak kemajuan yang dicapai dalam pembangunan pemberdayaan perempuan, yang antara lain ditandai dengan semakin meningkatnya status dan peran perempuan di berbagai aspek kehidupan, tetapi bila dibandingkan dengan kemajuan laki-laki, status dan peran perempuan masih tertinggal. Anggapan bahwa laki-laki lebih bebas serta perbedaan posisi sebagai pemimpin berdampak pada kesempatan perempuan untuk ikut berperan dalam pembangunan. Pemberian tugas akan cenderung diberikan terlebih dahulu dan banyak kepada laki-laki daripada perempuan (Vantina dkk., 2008).

Statistik tahun 2000 menunjukkan kondisi perempuan Indonesia 43 persen buta huruf. Angka kematian ibu (AKI) masih tinggi yaitu 390/ 100000. Tingkat partisipasi angkatan kerja (TPAK) perempuan lajang lebih rendah dibanding laki-laki yaitu sebesar 51,2 persen, sementara laki-laki 83,6 persen. Mayoritas perempuan yang bekerja menduduki posisi sebagai buruh (pekerja rendah) dengan pola penggajian yang berbeda dengan laki-laki (Setyasih, 2006). Fakta tersebut di atas menunjukkan masalah perempuan dan kesenjangan gender hingga saat ini masih terjadi hampir di semua bidang pembangunan. Tolok ukur untuk melihat keberhasilan peningkatan kesetaraan laki-laki perempuan adalah dengan indeks pembangunan gender (IPG).

Provinsi Jawa Tengah sebagai salah satu provinsi di Indonesia, angka IPG nya menunjukkan angka yang rendah dan masih berada di bawah angka nasional (Tabel 1).

Pada Tabel 1, IPG yang rendah menunjukkan masih adanya kesenjangan gender dan kualitas hidup perempuan yang masih rendah. Kualitas perempuan yang rendah akan mempengaruhi peran dalam pembangunan dan indeks pembangunan manusia. Indeks pembangunan manusia rendah akan mempengaruhi fundamental ekonomi daerah, untuk itulah penting untuk melakukan penelitian tentang peran wanita dalam pembangunan serta kausalitas anta-

Tabel 1. Perbandingan Indeks Pembangunan Gender antara Jawa Tengah dan Indonesia Tahun 2005 - 2008

\begin{tabular}{cccc}
\hline No & Tahun & Jawa Tengah & Indonesia \\
\hline 1 & 2005 & 59,8 & 63,9 \\
2 & 2006 & 60,8 & 65,1 \\
3 & 2007 & 63,7 & 65,3 \\
4 & 2008 & 64,7 & 66,4 \\
\hline
\end{tabular}

Sumber: Kementerian PP \&PA bekerjasama BPS (2009) 
ra indikator fundamental ekonomi daerah dan peran wanita dalam pembangunan. Penelitian ini mempunyai tujuan menganalis peran wanita dalam pembangunan di kabupaten/kota di Jawa Tengah serta menguji hubungan kausalitas antara fundamental ekonomi daerah dan peran wanita dalam pembangunan di kabupaten/ kota di Jawa Tengah.

Paradigma pembangunan modern memandang suatu pola yang berbeda dengan pembangunan ekonomi tradisional. Pertanyaan beranjak dari benarkah semua indikator ekonomi yang ada memberikan gambaran kemakmuran. Beberapa ekonom modern mulai mengedepankan dethronement of GNP (penurunan tahta pertumbuhan ekonomi), pengentasan kemiskinan, pengurangan ketimpangan distribusi pendapatan, dan penurunan tingkat pengangguran yang ada. Para ekonom tersebut membawa perubahan dalam paradigma pembangunan yang mulai menyoroti bahwa pembangunan harus dilihat sebagai suatu proses yang multidimensional (Kuncoro, 2004). Konsekuensi dari kualitas proses pembangunan adalah peningkatan kualitas sumber daya manusia. Penempatan manusia sebagai subyek pembangunan menekankan pada pentingnya pemberdayaan (empowerment) manusia, yaitu kemampuan untuk mengaktualisasikan segala potensi yang dimiliki masing-masing individu.

Keterkaitan sasaran fundamental ekonomi daerah antara pembangunan manusia dan pertumbuhan ekonomi dapat dilihat dari hasil penelitian Bank Pembangunan Asia (2007), yang menemukan bahwa pembangunan manusia berpengaruh positif terhadap pertumbuhan ekonomi baik secara langsung maupun tidak langsung. Pengaruh langsung pembangunan manusia terhadap pertumbuhan ditemukan bahwa tingkat melek huruf yang tinggi, tingkat kematian bayi yang rendah, dan tingkat kesenjangan serta kemiskinan yang rendah, memberikan kontribusi positif terhadap pertumbuhan ekonomi yang sangat cepat di Asia Timur dan Tenggara. Pengaruh tidak langsung pembangunan manusia terhadap pertumbuhan ekonomi ditemukan melalui konsolidasi demokrasi. Tingkat melek huruf yang tinggi, kesehatan yang baik, dan kesamaan kesempatan me- mungkinkan partisipasi masyarakat dalam proses politik dan membantu membangun konsensus atas tujuan pembangunan. Demokrasi yang partisipasif merupakan alat yang efektif bagi pengumpulan suara dan resolusi konflik yang pada gilirannya meningkatkan stabilitas politik dan sosial. Pembangunan yang memberdayakan masyarakat atau peran serta dan inisiatif lokal maka efisiensi pilihan investasi dan penyediaan jasa akan meningkat.

Penelitian dari UNSFIRS (2000) menyimpulkan bahwa pembangunan manusia bertindak sebagai variabel antara (shift variable) dalam hubungan antara pertumbuhan ekonomi dan demokrasi. Berinvestasi pada pembangunan manusia, maka sebuah daerah dapat bergerak ke arah pendapatan per kapita yang lebih tinggi dengan tingkat demokrasi tertentu melalui efek pertumbuhan langsung. Dampak tidak langsung HDI terhadap pertumbuhan ekonomi lewat demokrasi bertanggung jawab atas pergeseran non-paralel atas garis demokrasi-pendapatan perkapita. Dengan kata lain, hubungan antara pertumbuhan ekonomi dan demokrasi semakin kuat berkat kenaikan HDI.

Model pertumbuhan endogen menyediakan kerangka alternatif untuk meneliti hubungan antara pembangunan manusia, demokrasi dan pertumbuhan ekonomi. Studi antarnegara yang dilakukan oleh Barro (1991) menemukan hubungan sebab akibat antara tingkat kematian bayi dan pendidikan terhadap pertumbuhan ekonomi yang juga sejalan dengan teori "human capital ". Barro menolak hipotesis "trickle down" yang menyatakan bahwa pembangunan manusia hanya dapat dicapai melalui pertumbuhan ekonomi yang cepat.

Penelitian yang dilakukakan oleh Bhalla (1994) membawa perspektif lain, ia menemukan pengaruh positif demokrasi terhadap pertumbuhan. Menurut Bhalla, sebuah rezim demokratik cenderung lebih melindungi properti dan hak kontrak yang sangat penting untuk berjalannya mekanisme pasar yang didorong oleh sektor swasta. Penelitian Bhalla tidak secara langsung meneliti hubungan antara pertumbuhan ekonomi dan pembangunan manusia dengan membalik sebab akibat, namun penemuannya mengimplikasikan pendekatan "tric- 
kle down" terhadap pembangunan. Perhatiannya adalah pada daya tahan demokrasi. Ketika demokrasi berjalan dengan baik, pertumbuhan ekonomi akan berjalan dengan cepat dan akan menetes pada pembangunan manusia.

Pembangunan pemberdayaan perempuan merupakan bagian dari pembangunan sumber daya manusia, dan ditujukan untuk meningkatkan status, posisi dan kondisi perempuan agar dapat mencapai kemajuan yang setara dengan laki-laki. Pembangunan pemberdayaan perempuan merupakan salah satu prioritas pembangunan. Kualitas hidup dan partisipasi perempuan dalam pembangunan, terutama di bidang pendidikan, kesehatan, ekonomi dan politik, masih rendah, di samping masih adanya berbagai bentuk praktek diskriminasi dan eksploitasi. Disadari sudah banyak kemajuan yang dicapai dalam pembangunan pemberdayaan perempuan, yang antara lain ditandai dengan semakin meningkatnya status dan peran perempuan di berbagai aspek kehidupan, tetapi bila dibandingkan dengan kemajuan laki-laki, status dan peran perempuan masih tertinggal (Bappenas, 2008). Rendahnya kualitas hidup perempuan berpengaruh terhadap hasil perhitungan HDI.

\section{METODE PENELITIAN}

Penelitian ini memfokuskan analisis pada level daerah yaitu kabupaten/kota. Obyek penelitian ini adalah kabupaten/kota yang ada di Jawa Tengah yang berjumlah 29 kabupaten dan 6 kota. Secara keseluruhan ada 35 kabupaten/ kota. Penelitian ini menggunakan data sekunder, yaitu data yang diperoleh dari pihak lain berupa data jadi dalam bentuk publikasi. Data tersebut diperoleh dari berbagai sumber, yaitu: Biro Pusat Statistik (BPS), internet data yang diperlukan: Produk Domestik Regional Bruto, pendidikan terakhir yang ditamatkan tenaga kerja wanita, jumlah wanita yang mengikuti program keluarga berencana, jumlah wanita bekerja di masing-masing bidang, jumlah angkatan kerja wanita. Periode data penelitian ini adalah runtun waktu mulai tahun 2001-2009.

Adapun definisi operasional variabel yang digunakan adalah sebagai berikut: Fundamental Ekonomi, yang digunakan sebagai indikator fundamental ekonomi adalah Pertumbuhan ekonomi, yang diukur Produk Domestik regional Bruto (PDRB) berdasar harga konstan 2000. Peran Wanita dalam penelitian ini menggunakan indikator yang digunakan Indrayanti dkk. (2007), ada empat indikator peran wanita yang digunakan pertama, tingkat pendidikan diukur dengan jumlah tenaga kerja wanita berdasarkan pendidikan terakhir yang ditamatkan dan rasio tenaga kerja wanita dan laki-laki berdasarkan pendidikan terakhir yang ditamatkan. Kedua, tingkat kesehatan diukur dengan jumlah wanita yang mengikuti program kelurga berencana dan jumlah wanita pengikut keluarga berencana mandiri. Ketiga, peran wanita di sektor publik diukur dengan jumlah wanita yang bekerja di berbagai bidang. Keempat, potensi ketenagakerjaan diukur dengan jumlah angkatan kerja wanita yang bekerja, rasio angkatan kerja yang bekerja antara wanita dan laki-laki dan jumlah wanita berusaha sendiri.

Metode pengumpulan data dalam penelitian ini adalah dokumentasi, yaitu salah satu metode pengumpulan data yang diperoleh dari dokumen/tulisan yang disusun oleh badan/ pihak yang dapat dipertanggungjawabkan kevaliditasannya (Kuncoro, 2003), dalam hal ini dokumen tersebut adalah laporan periodik yang dikeluarkan oleh Biro Pusat Statistik. Untuk menguji hubungan kausalitas antara fundamental ekonomi daerah dan peran wanita digunakan Uji kausalitas Granger. Uji Kausalitas dilakukan karena ada tiga kemungkinan arah kausalitas. Pertama, variabel $\mathrm{X}$ menyebabkan variabel $Y$, Kedua, variabel $\mathrm{Y}$ menyebabkan variabel $X$, Ketiga, hubungan timbal balik variabel $X$ menyebabkan variabel $Y$ dan pada saat yang sama variabel $Y$ menyebabkan variabel $X$ (Kuncoro, 2001). Model dasar penelitian yang digunakan dapat diformulasikan sebagai berikut:

$$
\begin{aligned}
& Y_{t}=\sum a_{i} Y_{t-i}+\sum b_{j} X_{t-j}+v_{t} \\
& X_{t}=\sum c_{i} X_{t-i}+\sum d_{j} X_{t-j}+\mu_{t}
\end{aligned}
$$

dimana: $\mathbf{Y}$ adalah fundamental ekonomi daerah; $\mathbf{X}$ adalah peran wanita; $\mathbf{a}, \mathbf{b}, \mathbf{c}, \mathbf{d}$ adalah koefisien; $\mathbf{t}$ adalah waktu; $\mathbf{i}, \mathbf{j}$ adalah $1,2,3 \ldots \mathbf{k} ; \mathbf{v}, \mathbf{p}$ adalah error. 


\section{HASIL DAN PEMBAHASAN}

\section{Peran Wanita dalam Pembangunan}

Pendidikan merupakan salah satu indikator pembangunan sektor wanita. Perbedaan tingkat pendidikan akan menghasilkan perbedaan kontribusi wanita dalam pembangunan. Tingkat pendidikan wanita yang dijadikan indikator pembangunan sektor wanita dilihat dari pendidikan rendah wanita (tidak/belum pernah sekolah, tidak/belum tamat SD/MI, tamat SD/ $\mathrm{MI}$ ), pendidikan menengah (tamat SLTP, tamat SMU/SMK), pendidikan tinggi (tamat diploma dan sarjana).

Proporsi pendidikan wanita di Jawa Tengah dapat dilihat pada Gambar 1. Gambar 1 menunjukkan masih rendahnya tingkat pendidikan wanita. Penduduk wanita yang berpendidikan rendah di Jawa Tengah tahun 2006 menunjukkan 69 persen yang berarti sebagian besar pendidikan wanita di Jawa Tengah (tidak/belum pernah sekolah, tidak/belum tamat $\mathrm{SD} / \mathrm{MI}$, tamat SD/MI).

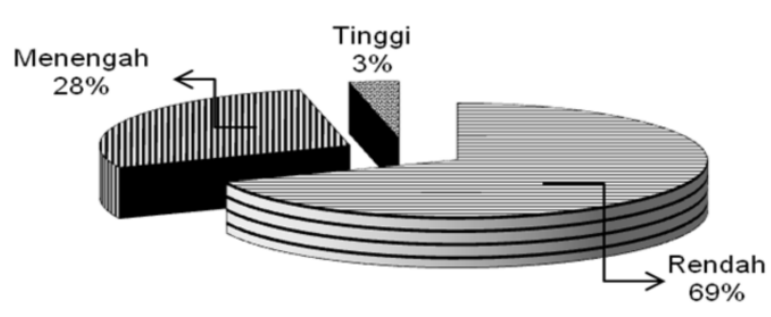

Sumber: BPS, Statistik Sosial dan Kependudukan Jawa Tengah (2008)

\section{Gambar 1. Tingkat Pendidikan Wanita di Jawa Tengah Tahun 2006}

Penduduk wanita yang berpendidikan menengah (tamat SLTP, tamat SMU/SMK) sebesar 28 persen sedangkan yang berpendidikan tinggi hanya 3 persen. Rendahnya pendidikan wanita ini akan sangat mempengaruhi pembangunan di Jawa Tengah sehingga pemerintah Provinsi Jawa Tengah harus lebih memperhatikan terhadap kebijakan pendidikan.

Tahun 2004, kabupaten/kota yang pendi- dikan wanitanya rendah paling tinggi, berturutturut adalah kabupaten Brebes (86,8 persen), kabupaten Wonosobo (85,5 persen) dan Kabupaten Pemalang (82 persen). Pada tahun 2005, kabupaten/kota yang pendidikan wanitanya rendah masing-masing Kabupaten Wonosobo (84,8 persen), kabupaten Brebes (82,9 persen) dan kabupaten Grobogan (81,4 persen). Pendidikan Wanita yang rendah pada tahun 2006 menurut kabupaten/kota adalah kabupaten Brebes (82,5 persen), kabupaten Banjarnegara (80,9 persen) dan kabupaten Wonosobo (80 persen). Dilihat dari tingkat pendidikan (Gambar 2) dapat disimpulkan bahwa di Jawa Tengah yang terdiri dari 35 kabupaten/kota pada tahun pengamatan 2004-2006 ada dua kabupaten yang pendidikan wanitanya sangat rendah yaitu kabupaten Brebes dan kabupaten Wonosobo, yang penduduk wanitanya lebih dari 80 persen pendidikan rendah. Hal ini terjadi karena di kedua kabupaten tersebut sektor yang menjadi andalan adalah sektor pertanian yang relatf tidak membutuhkan persyaratan pendidikan formal tinggi. Kabupaten Brebes produk andalannya adalah pertanian bawang merah, dan kabupaten Wonosobo perkebunan tembakau.

Tahun 2004, kabupaten/kota yang pendidikan wanitanya tinggi paling tinggi, berturutturut adalah kota Salatiga (9,6 persen), kota Magelang (8,2 persen) dan Kota Semarang (7,4 persen). Pada tahun 2005, kabupaten/kota yang pendidikan wanitanya tinggi masing-masing kota Semarang (7,4 persen), kota Magelang $(8,2$ persen) dan kota Surakarta (7,2 persen). Pendidikan Wanita yang tinggi pada tahun 2006 menurut kabupaten/kota adalah kota Magelang (8,2 persen), Kota Surakarta (7,2 persen) dan kota Semarang (7,4 persen). Gambar 3 dapat disimpulkan bahwa di Jawa Tengah yang terdiri dari 35 kabupaten/kota pada tahun pengamatan 2004-2006 ada dua kabupaten yang pendidikan wanitanya sangat tinggi yaitu kota Magelang dan kota Semarang. Hal ini disebabkan Kota Magelang secara geografis berbatasan dengan Provinsi DIY yang notabene kota pelajar sehingga memungkinkan penduduknya untuk menuntut ilmu yang lebih tinggi terjangkau sedangkan kota Semarang sebagai ibukota pro- 
Proporsi Pendidikan Rendah Wanita Menurut Kab/ Kota di Jawa Tengah Tahun 2004 - 2006 ( \% )

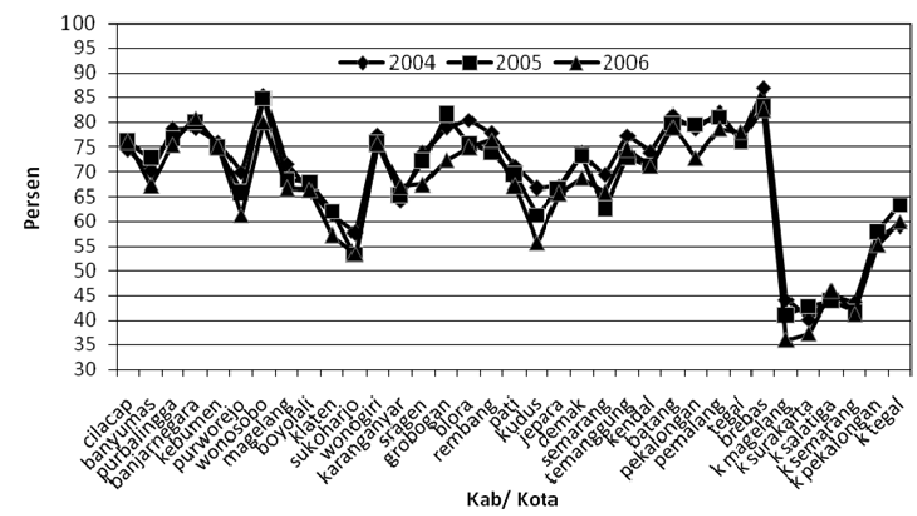

Sumber: BPS, Statistik Sosial dan Kependudukan Jateng (2008)

Gambar 2. Proporsi Pendidikan Rendah Wanita Menurut Kab/Kota di Jawa Tengah Tahun 2004$2006(\%)$

vinsi Jawa Tengah memiliki jumlah perguruan tinggi banyak sehingga mempermudah pilihan sekolah tinggi, tetap berdomisili di kota Semarang dan hemat biaya hidup.

Perbandingan pendidikan yang ditamatkan antara penduduk laki-laki dan wanita di kabupaten/kota di Jawa Tengah masih tampak bahwa pendidikan penduduk laki-laki masih jauh lebih tinggi daripada wanita. Rata-rata pendidikan laki-laki yang ditamatkan, untuk pendidikan rendah 59,5 persen sedangkan wanita 66,5 persen. Pendidikan menengah ratarata penduduk laki-laki 36,2 persen, wanita 29,9 persen yang berarti lebih tinggi pendidikan wanita yang ditamatkan. Pendidikan yang ditamatkan laki-laki untuk pendidikan tinggi 4,4 persen sedangkan wanita 3,7 persen. Hal ini dapat disimpulkan bahwa pada umumnya pendidikan yang ditamatkan penduduk wanita lebih rendah dibandingkan laki-laki yang berarti proses pengarustamaan gender masih perlu ditingkatkan (Gambar 3).

Tingkat kesehatan wanita yang berhubungan dengan pembangunan sektor wanita ditandai dengan banyaknya peserta keluarga berencana (KB) aktif yang menggunakan alat KB. Penggunaan metode kontrasepsi dapat dengan metode kontrasepsi jangka panjang (alat kontrasepsi dalam rahim/AKDR IUD, medis operasi wanita/MOW, susuk/implant) maupun non metode kontrasepsi jangka panjang (suntik, pil, obat vaginal). Penggunaan alat kontrasepsi peserta KB aktif dijadikan indikator tingkat kesehatan wanita karena wanita yang sadar menggunakan alat KB memiliki tingkat kesehatan reproduksi yang lebih baik dibandingkan wanita yang tidak sadar menggunakan alat KB.

Peserta KB di kabupaten/kota di Jawa Tengah tahun 2006, rata-rata 28,4 persen dari penduduk wanita usia produktif dan kawin. Angka ini masih dianggap kecil karena belum melebihi 50 persen penduduk wanita usia kawin yang sadar akan kesehatan. Penyebab masih kurangnya peserta $\mathrm{KB}$ adalah kurangnya informasi tentang penggunaan alat kontrasepsi baik metode, cara dan efek sampingnya. Berkaitan dengan hal tersebut perlu peran serta Posyandu, puskesmas atau klinik-klinik yang ada untuk bisa lebih aktif mengadakan penyuluhan-penyuluhan dan pelayanan kepada masyarakat khususnya wanita usia produktif dan kawin. Dilihat dari per kabupaten/kota, kabupaten Rembang menempati posisi peserta KB tertinggi (36 persen). Posisi kedua diduduki kabupaten Banjarnegara (33,9 persen) dan ketiga kabupaten Wonogiri (33,4 persen). Kalau dilihat dari segi perekonomiannya, kabupaten-kabupaten tersebut bukan kabupaten yang memiliki pertumbuhan ekonomi atau Produk Domestik Regional Bruto (PDRB) tinggi, namun mempunyai tingkat kesadaran tentang kesehatan alat 


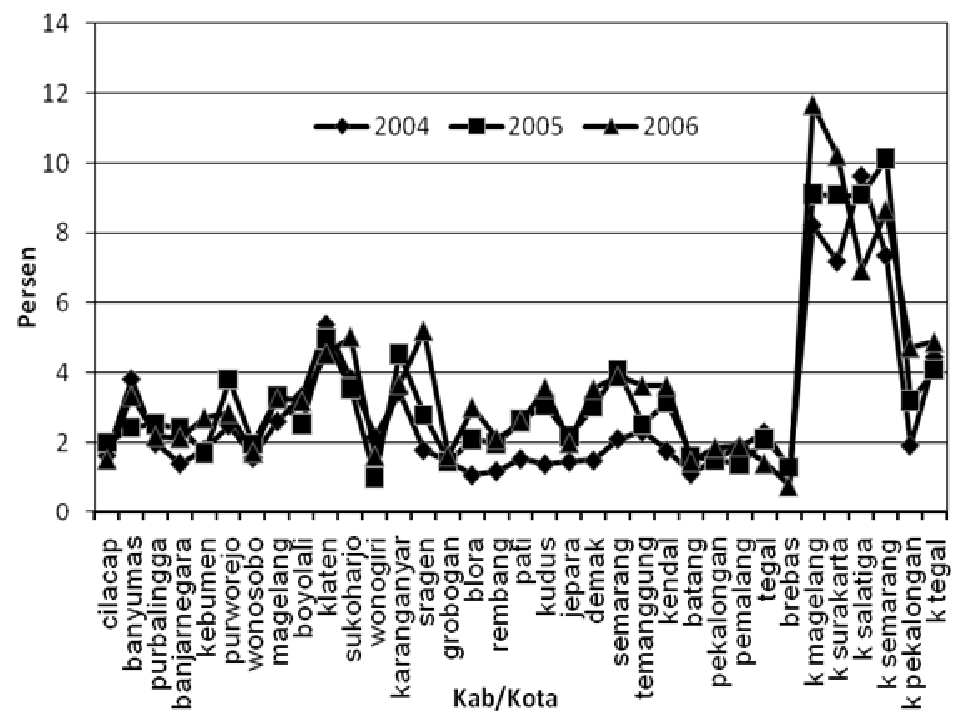

Sumber: BPS, Statistik Sosial dan Kependudukan Jateng (2008)

Gambar 3. Proporsi Pendidikan Tinggi Wanita Menurut Kab/ Kota di Jawa Tengah Tahun 2004- 2006 (\%)

reproduksi tinggi dibandingkan kabupatenkabupaten lainnya di Jawa Tengah (Gambar 4).

Indikator lain yang bisa digunakan untuk melihat kesehatan wanita adalah dari peserta $\mathrm{KB}$ aktif menurut jalur kemandirian. Peserta KB mandiri ini lebih menunjukkan tingkat kesadar- an kesehatan alat reproduksi yang tinggi. Tahun 2004, kabupaten/kota yang peserta KB mandirinya paling tinggi, berturut-turut adalah Kota Magelang (82, 6 persen), Kota Pekalongan (75, 9 persen) dan Kota Salatiga (70,5 persen). Pada tahun 2005, kabupaten/kota yang peserta

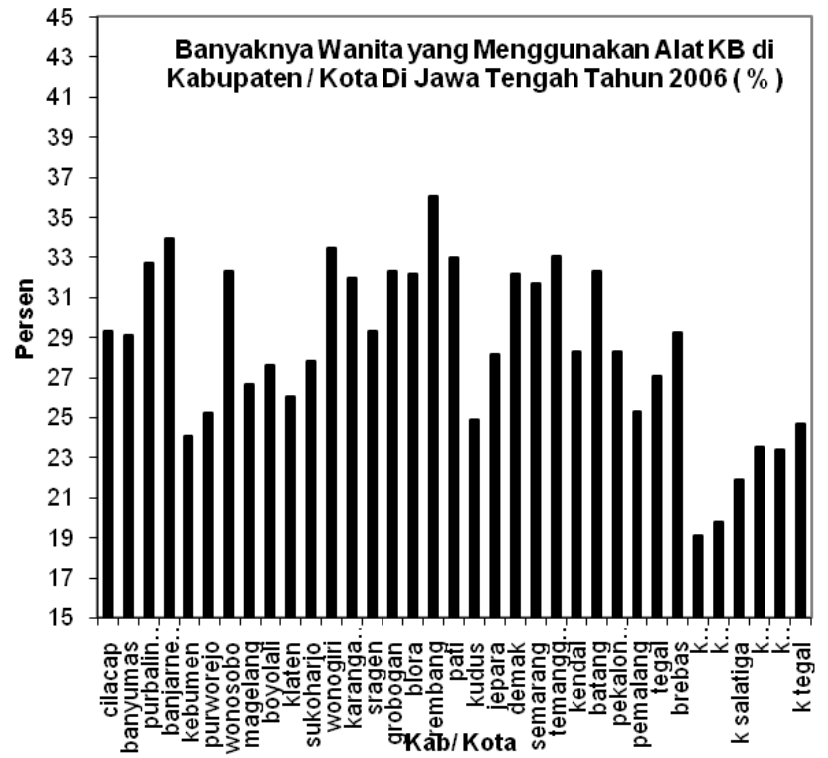

Sumber: BPS, Jawa Tengah dalam Angka (2008)

Gambar 4. Banyaknya Wanita yang Menggunakan Alat KB di Kabupaten/Kota di Jawa Tengah Tahun $2006(\%)$ 


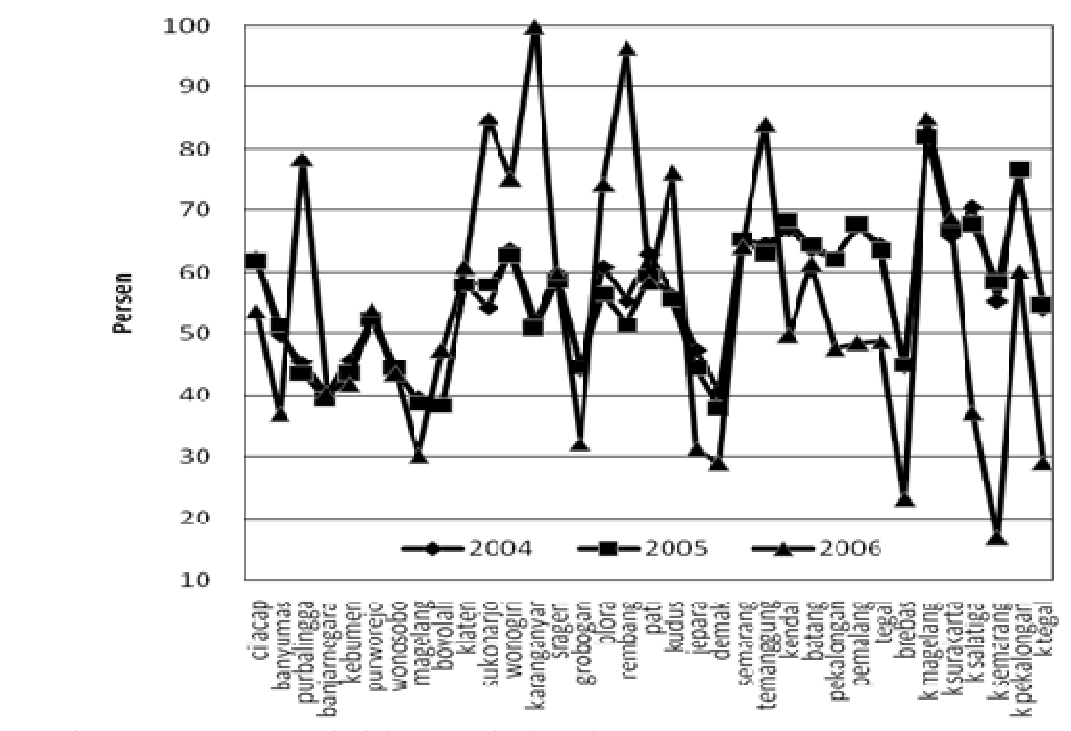

Sumber: BPS, Jawa Tengah dalam Angka (2008)

\section{Gambar 5. Proporsi Wanita KB Aktif Menurut Jalur Kemandirian Kab/Kota di Jawa Tengah Tahun 2004-2006 ( \% )}

KB mandirinya tinggi masing-masing kota Magelang (81,8 persen), kota Pekalongan (76,5 persen) dan kabupaten Kendal (68, 5 persen). Peserta KB mandiri tinggi pada tahun 2006 menurut kabupaten/kota adalah kota Salatiga (137,1 persen), kabupaten Karanganyar (99,9 persen) dan kabupaten Rembang (96,4 persen). Provinsi Jawa Tengah yang terdiri dari 35 kabupaten/kota pada tahun pengamatan 20042006 ada dua kabupaten yang peserta KB mandirinya tinggi yaitu kota Magelang dan kota Pekalongan. Hasil ini tidak konsisten dengan indikator kesehatan sebelumnya, yang melihat hanya dari peserta KB aktif, dimana kabupaten Rembang, kabupaten Banjarnegara, kabupaten Wonogiri menempati posisi tiga teratas (Gambar 5).

Rata-rata peserta KB mandiri di kabupaten/kota di Jawa Tengah tahun 2004 adalah 56,5 persen dari peserta KB aktif, tahun 2005 rata-rata turun sedikit menjadi 55,9 persen serta tahun 2006 rata-rata 58 persen. Dari indikator kesehatan peserta KB mandiri, dapat disimpulkan bahwa wanita di kabupaten/kota di Jawa Tengah tingkat kesehatannya khususnya alat reproduksi tinggi.

Di Jawa Tengah tahun 2006, ruang publik yang sudah dimasuki oleh wanita ada beberapa sektor: sektor pertanian, perdagangan, industri, jasa, sementara sektor pertambangan dan galian, listrik, gas dan air, konstruksi, komunikasi, keuangan dan lainnya sangat kecil (kurang dari 1 persen). Peran wanita dalam sektor publik, dapat dilihat dari banyaknya wanita yang bekerja pada masing-masing bidang lapangan usaha. Pada Gambar 6 dapat dilihat proporsi wanita pada masing-masing bidang.

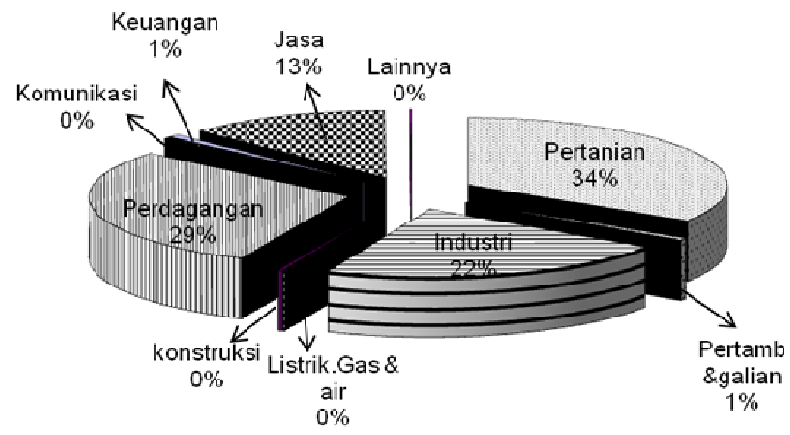

Sumber: BPS, Statistik Sosial dan Kependudukan Jateng (2008)

\section{Gambar 6. Proporsi Wanita di Sektor Publik di Jawa Tengah Tahun 2006}

Sektor publik yang paling banyak menyerap perhatian dan peran wanita adalah sektor 
pertanian (34 persen). Kondisi ini adalah wajar karena pada dasarnya sebagian besar wilayah Jawa Tengah umumnya merupakan daerah agraris. Sejauh ini sektor agraris masih menjadi tumpuan utama perekonomian nasional maupun regional, sifatnya fleksibel, serta tidak ada persyaratan khusus (pendidikan formal) untuk memasukinya seakan menjadi peluang besar bagi siapapun untuk bergerak di dalamnya, termasuk kaum wanita.

Sektor publik lain yang banyak terisi oleh peranan kaum wanita adalah perdagangan (29,5 persen), industri (21,9 persen), dan jasa (12,7 persen). Sementara, sektor yang belum banyak tersentuh oleh peran publik wanita adalah: Keuangan (0,7 persen), pertambangan dan galian $(0,5$ persen), komunikasi $(0,4$ persen), konstruksi ( 0,3 persen), dan listrik $(0,1$ persen) serta lainnya (0,1 persen).

Indikator lain yang dapat digunakan untuk melihat pembangunan sektor wanita yaitu ketenagakerjaan. Indikator ketenagakerjaan yang digunakan adalah banyaknya proporsi wanita sebagai angkatan kerja yang bekerja dan proporsi wanita yang bekerja berusaha sendiri tanpa bantuan orang lain. Pada dasarnya penduduk dapat dibagi dalam dua kelompok, yaitu penduduk yang termasuk dalam kelompok angkatan kerja dan penduduk yang bukan angkatan kerja.

Penduduk yang berumur 10 tahun ke atas yang termasuk dalam kelompok angkatan kerja adalah mereka yang selama seminggu yang lalu mempunyai pekerjaan, baik yang bekerja maupun yang sementara tidak bekerja karena suatu sebab seperti menunggu panen dan pegawai cuti. Penduduk yang berumur 10 tahun ke atas dan tidak mempunyai pekerjaan tetapi sedang mencari pekerjaan/mengharapkan dapat pekerjaan juga termasuk dalam kelompok angkatan kerja. Penduduk berumur 10 tahun ke atas yang termasuk dalam kelompok bukan angkatan kerja adalah penduduk yang hanya bersekolah, mengurus rumah tangga dan sebagainya, dan tidak melakukan suatu kegiatan yang dapat dimasukkan dalam kategori bekerja, sementara tidak bekerja atau mencari pekerjaan.

Tahun 2004, rata-rata angkatan kerja wani- ta yang bekerja 93 persen, pada tahun 2005 ratarata angkatan kerja wanita yang bekerja 92,8 persen sedangkan pada tahun 2006 sebesar 91,4 persen. Dari angka tersebut dapat disimpulkan bahwa proporsi angkatan kerja wanita yang bekerja lebih besar dibandingkan yang tidak bekerja (sedang mencari pekerjaan). Proporsi angkatan kerja wanita yang tidak bekerja, pada tahun 2004 sebesar 8 persen, pada tahun 2005 sebesar 7,2 persen serta 8,6 persen pada tahun 2006. Hal ini menunjukkan bahwa dari keseluruhan wanita di Jawa Tengah, sebagian besar memiliki kegiatan produktif. Tahun 2004 Kabupaten/kota yang angkatan kerja wanita bekerja tinggi adalah kabupaten Purworejo (97 persen), kabupaten Semarang $(96,8)$ dan kabupaten Temanggung (96,2 persen). Tahun 2005, angkatan kerja wanita yang bekerja tinggi adalah kabupaten Temanggung (96 persen), kabupaten Pati (96,4 persen), dan kabupaten Sragen (96,4 persen). Pada tahun 2006, kabupaten Jepara menempati posisi pertama ( 96,5 persen), kabupaten Sragen pada posisi kedua (96 persen) dan kabupaten Kudus pada posisi ketiga (96 persen). Kabupaten/kota yang angkatan kerja wanitanya bekerja mempunyai proporsi tinggi tersebut adalah kabupaten/kota yang termasuk daerah industri, sehingga memungkinkan kesempatan kerja yang ada lebih banyak. Tingginya angkatan kerja wanita yang bekerja menunjukkan bahwa peran wanita dalam pembangunan meningkat (Gambar 7).

Proporsi angkatan kerja wanita yang bekerja dibandingkan dengan angkatan kerja lakilaki yang bekerja masih di bawah laki-laki meskipun tidak terlalu menyolok. Hal ini menunjukkan bahwa peran wanita meningkat dan pengarustamakan gender sudah bisa dikatakan ada hasilnya. Indikator lain untuk melihat potensi ketenagakerjaan wanita adalah banyaknya angkatan kerja wanita yang bekerja dengan status pekerjaan utama berusaha sendiri tanpa bantuan orang lain, berusaha dengan dibantu buruh tidak tetap, berusaha dengan dibantu buruh tetap, buruh/karyawan pekerja dibayar, pekerja bebas pertanian, pekerja bebas non pertanian, pekerja tak dibayar. Provinsi Jawa Tengah tahun 2006, angkatan kerja wanita yang bekerja dengan status pekerjaan utama ber- 


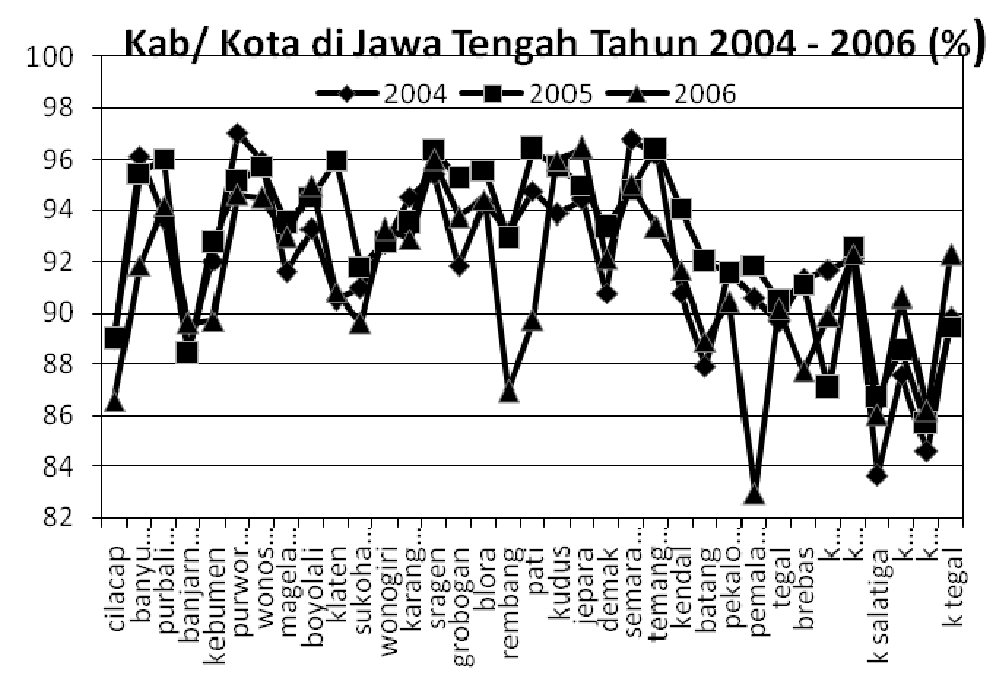

Sumber: BPS, Statistik Sosial dan Kependudukan Jateng (2008)

Gambar 7. Proporsi Angkatan Kerja Wanita yang Bekerja Menurut Kabupaten/Kota di Jawa Tengah Tahun $2004-2006$ ( \% )

usaha sendiri tanpa bantuan orang lain sebesar (22,2 persen), berusaha dengan dibantu buruh tidak tetap (11,7 persen), berusaha dengan dibantu buruh tetap $(1,6$ persen), buruh/karyawan pekerja dibayar (26,6 persen), pekerja bebas pertanian $(7,5$ persen), pekerja bebas non pertanian (2,7 persen), pekerja tak dibayar $(27,8$ persen). Hal ini menunjukkan bahwa peran wanita dalam pembangunan masih kurang karena proporsi pekerja tak dibayar paling besar, menyusul buruh/karyawan pekerja dibayar (Gambar 8).
Hubungan Kausalitas Antara Indikator Fundamental Ekonomi Daerah dengan Peran Wanita dalam Pembangunan

Untuk menguji hubungan kausalitas antara indikator fundamental ekonomi daerah dengan peran wanita dalam pembangunan digunakan uji kausalitas Granger. Ada beberapa tahapan dan persyaratan yang dilakukan untuk menggunakan alat uji tersebut. Pengujian tersebut berkaitan erat dengan pengujian terhadap kemungkinan adanya hubungan keseimbangan jangka panjang antara variabel-variabel ekonomi.

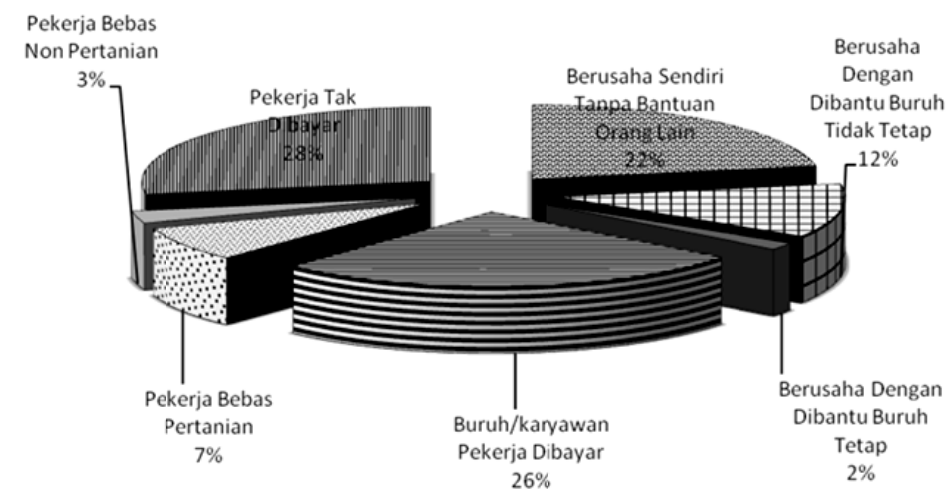

Sumber: BPS, Statistik Sosial dan Kependudukan Jateng (2008)

Gambar 8. Angkatan Kerja Wanita yang Bekerja Menurut Status Pekerjaan Utama di Jawa Tengah Tahun 2006 
Berkaitan dengan isu tersebut, pengujian terhadap perilaku data runtun waktu (time series) atau integrasinya dapat dipandang sebagai uji prasyarat bagi digunakannya pendekatan model dinamis.Untuk itu, pertama-tama harus diamati perilaku data runtun waktu yang akan digunakan stasioner atau tidak. Selanjutnya, apabila diyakini bahwa variabel-variabel yang diamati mempunyai derajat integrasi yang sama, maka dapat diuji residual variabel yang dihasilkan stationer atau tidak.

\section{Uji Akar-Akar Unit}

Indikator yang digunakan untuk mengukur variabel fundamental ekonomi daerah adalah pertumbuhan PDRB berdasarkan harga konstan 2000 dari tahun 2001-2009 sampai bulan Februari (growth). Sedangkan indikator variabel peran wanita hanya dilihat dari persentase tingkat pendidikan tinggi yang ditamatkan (edu) dan potensi ketenagakerjaan dilihat dari persentase angkatan kerja wanita yang bekerja (LF). Alasan hanya dua indikator yang diambil untuk melihat peran wanita adalah karena ketidakkonsistenan data sekunder yang ada, ketersediaan data runtun waktu dan tidak stationernya data pada uji awal. Hasil pengolahan data dengan menggunakan program Eviews 6, secara ringkas hasil uji akar-akar unit bisa dilihat pada Tabel 2.

Tabel 2. Hasil Uji Akar-Akar Unit Variabel Pertumbuhan PDRB (growth), Pendidikan yang Ditamatkan (Edu) dan Angkatan Kerja yang Bekerja (LF)

\begin{tabular}{lcl}
\hline Variabel & Nilai DF & Nilai ADF \\
\hline Growth & $-14,851^{*}$ & $-6,160^{* *}$ \\
Edu & 1,078 & $-1,757$ \\
LF & $-1,839$ & $-1,781$ \\
\hline
\end{tabular}

Ket : * sig pada $\alpha=1 \%,{ }^{* *} \operatorname{sig}$ pada $\alpha=5 \%$

Uji akar-akar unit menggunakan uji Dickey dan Fuller, kemudian dilihat dari nilai statistik Dickey-Fuller (DF) dan Augmented Dickey-Fuller (ADF). Pada Tabel 2 dapat diketahui bahwa hasil uji akar-akar unit untuk variabel growth nilai statistik baik nilai DF maupun nilai ADF signifikan artinya data tersebut sudah stasioner, tetapi untuk variabel Edu dan LF belum signifikan artinya belum stationer sehingga harus dilakukan uji tahap berikutnya yaitu uji integrasi.

\section{Uji Integrasi}

Uji integrasi dilakukan terhadap variabel Edu dan LF yang pada uji akar unit belum stationer. Untuk ringkasnya hasil uji integrasi dapat dilihat pada Tabel 3 .

Tabel 3. Hasil Uji Integrasi Pertama Variabel Pendidikan yang Ditamatkan (Edu) dan Angkatan Kerja yang Bekerja (LF)

\begin{tabular}{llc}
\hline Variabel & Nilai DF & Nilai ADF \\
\hline Edu & $-2,933^{* * *}$ & $-3,589$ \\
LF & $-6,077^{*}$ & $-5,166^{* *}$ \\
\hline
\end{tabular}

Ket : * sig pada $\alpha=1 \%,{ }^{* *} \operatorname{sig}$ pada $\alpha=5 \%,{ }^{* *} \operatorname{sig}$ pada $\alpha=10 \%$

Hasil uji integrasi pertama pada Tabel 3, menunjukkan bahwa variabel Edu nilai statistik ADF belum signifikan yang berarti belum stasioner, untuk itu harus dilakukan uji integrasi kedua. Secara ringkas dapat dilihat pada Tabel 4.

Tabel 4. Hasil Uji Integrasi Kedua Variabel Pendidikan yang Ditamatkan (Edu)

\begin{tabular}{lcc}
\hline Variabel & Nilai DF & Nilai ADF \\
\hline Edu & - & $-10,912 *$ \\
\hline
\end{tabular}

Ket : ${ }^{*} \operatorname{sig}$ pada $\alpha=1 \%$

Hasil uji akar-akar unit dan integrasi baik integrasi pertama maupun kedua, telah menunjukkan data stasioner, artinya bisa dilanjutkan pada tahap uji berikutnya yaitu uji kointegrasi. 


\section{Uji Kointegrasi}

Pengujian terhadap suatu model empiris apakah mempunyai hubungan kointegrasi, maka ada tiga nilai yang perlu diperhatikan, yaitu nilai statistik Cointegration-Regression Durbin Watson (CRDW), DF dan ADF. Ketiga nilai tersebut ditaksir dengan regresi kointegrasi dengan metode kuadrat terkecil (Ordinary Least Square). Hasil pengolahan data dengan menggunakan program Eviews 6 secara, untuk ringkasnya dapat dilihat pada Tabel 5 .

Tabel 5. Hasil Uji Kointegrasi Kausalitas Variabel Pertumbuhan PDRB (growth) dan Pendidikan yang Ditamatkan Wanita (Edu)

\begin{tabular}{|c|c|c|c|}
\hline \multicolumn{2}{|c|}{$\begin{array}{c}\text { Variabel Tak Bebas: } \\
\text { Growth }\end{array}$} & \multicolumn{2}{|c|}{$\begin{array}{c}\text { Variabel Tak Bebas: } \\
\text { Edu }\end{array}$} \\
\hline Variabel & Nilai & Variabel & Nilai \\
\hline Bebas & $\begin{array}{l}\text { Koefisien } \\
\text { dan } \mathrm{t} \\
\text { Statistik }\end{array}$ & Bebas & $\begin{array}{l}\text { Koefisien } \\
\text { dan } t \\
\text { Statistik }\end{array}$ \\
\hline Konstanta & $\begin{array}{l}3,870 \\
(6,387)\end{array}$ & Konstanta & $\begin{array}{c}-2,113 \\
(-0,693)\end{array}$ \\
\hline Edu & $\begin{array}{c}0,294 \\
(1,908)\end{array}$ & Growth & $\begin{array}{c}1,164 \\
(1,908)\end{array}$ \\
\hline $\begin{array}{l}\text { CRDW }=0,7 \\
\mathrm{DF}=-1,947 \\
\mathrm{ADF}=-2,65\end{array}$ & & $\begin{array}{l}\text { CRDW }=0,7 \\
\mathrm{DF}=-0,950 \\
\mathrm{ADF}=-1,422\end{array}$ & \\
\hline
\end{tabular}

Ket: angka ( ) menunjukkan t statistik

Berdasarkan Tabel 5, dapat disimpulkan bahwa dengan $\alpha=5 \%$ residual persamaan kointegrasi tidak stationer pada derajat 0 yang ditandai dengan tidak signifikansinya nilai CRDW, DF dan ADF secara statistik (nilai CRDW tabel, DF tabel, ADF tabel masing-masing 0,$78 ; 3,67$; dan 3,29). Hasil ini menunjukkan bahwa antara growth sebagai indikator fundamental ekonomi daerah dan pendidikan yang ditamatkan wanita sebagai indikator dari peran wanita tidak ditemukan adanya pola kausalitas, artinya semakin tinggi pendidikan yang ditamatkan wanita tidak menyebabkan pertumbuhan ekonomi suatu wilayah meningkat atau se- baliknya semakin tinggi pertumbuhan ekonomi suatu wilayah tidak menyebabkan pendidikan yang ditamatkan wanita semakin tinggi.

Indikator yang kedua untuk melihat peran wanita dalam pembangunan adalah potensi ketenagakerjaan yaitu jumlah angkatan kerja wanita yang bekeja. Hasil pengolahan data dengan program Eviews 6 uji kointegrasi secara ringkas, untuk indikator kedua dari peran wanita dapat dilihat pada Tabel 6

Tabel 6. Hasil Uji Kointegrasi Kausalitas Variabel Pertumbuhan PDRB (growth) dan Angkatan Kerja Wanita yang Bekerja (LF)

\begin{tabular}{|c|c|c|c|}
\hline \multicolumn{2}{|c|}{$\begin{array}{c}\text { Variabel Tak Bebas: } \\
\text { Growth }\end{array}$} & \multicolumn{2}{|c|}{$\begin{array}{c}\text { Variabel Tak Bebas: } \\
\text { LF }\end{array}$} \\
\hline Variabel & Nilai & Variabel & Nilai \\
\hline Bebas & $\begin{array}{l}\text { Koefisien } \\
\text { dan } t \\
\text { Statistik }\end{array}$ & Bebas & $\begin{array}{l}\text { Koefisien } \\
\text { dan } \mathrm{t} \\
\text { Statistik }\end{array}$ \\
\hline Konstanta & $\begin{array}{c}1,212 \\
(0,671)\end{array}$ & Konstanta & $\begin{array}{l}4254416 \\
(3,479)\end{array}$ \\
\hline LF & $\begin{array}{l}0,0000006 \\
(0,213)\end{array}$ & Growth & $\begin{array}{l}335327,1 \\
(1,370)\end{array}$ \\
\hline \multicolumn{2}{|c|}{$\mathrm{CRDW}=0,594$} & \multicolumn{2}{|c|}{$C R D W=1.456$} \\
\hline \multicolumn{2}{|c|}{$\mathrm{DF}=-3,752$} & \multicolumn{2}{|c|}{$\mathrm{DF}=-3,159$} \\
\hline \multicolumn{2}{|l|}{$\mathrm{ADF}=-2,53$} & \multicolumn{2}{|c|}{$\mathrm{ADF}=-2,282$} \\
\hline
\end{tabular}

Ket: angka ( ) menunjukkan t statistik

Berdasarkan Tabel 6, dapat disimpulkan bahwa dengan $\alpha=5 \%$ residual persamaan kointegrasi tidak stationer pada derajat 0 yang ditandai dengan tidak signifikansinya nilai CRDW, DF dan ADF secara statistik (nilai CRDW tabel, DF tabel, ADF tabel masingmasing 0,$78 ; 3,67 ; 3,29$ ) untuk persamaan yang variabel tak bebasnya growth dan bebasnya LF. Hasil lain menunjukkan persamaan yang variabel tak bebasnya LF dan bebasnya growth, nilai statistik CRDW-nya signifikan. Hal ini menunjukkan bahwa antara growth sebagai indikator fundamental ekonomi daerah dan angkatan kerja wanita yang bekerja sebagai indikator dari peran wanita ditemukan adanya pola 
kausalitas searah, artinya semakin tinggi angkatan kerja wanita yang bekerja menyebabkan pertumbuhan ekonomi suatu wilayah meningkat tetapi sebaliknya semakin tinggi pertumbuhan ekonomi suatu wilayah tidak menyebabkan angkatan kerja wanita yang bekerja meningkat.

\section{Uji Kausalitas Granger}

Setelah uji akar unit, uji integrasi dan uji kointegrasi, tahapan yang terakhir adalah uji kausalitas Granger. Panjang kelambanan (lag) dalam pengujian kausalitas granger ini, ditetapkan masing-masing sebesar 2. Kegunaan uji kausalitas Granger untuk mengetahui hubungan kausal dari dua variabel, apakah hubungan yang timbal balik, searah atau bahkan tidak ditemukan pola hubungan kausal dalam konteks jangka pendek. Hasil pengolahan data dengan menggunakan program Eviews 6, uji kausalitas Granger dapat dilihat pada Tabel 7.

Berdasarkan Tabel 7, ada hubungan kausalitas antara angkatan kerja wanita yang bekerja sebagai indikator peran wanita dalam pembangunan dengan pertumbuhan PDRB sebagai indikator fundamental ekonomi daerah. Hal ini ditunjukkan dengan hasil uji kausalitas Granger dengan null hypothesis antara LF dan growth dengan nilai prob 0,0576 (sig pada nilai $\alpha=10 \%$ ). Semakin tinggi angkatan kerja wanita yang bekerja yang berarti peran wanita dalam pembangunan meningkat menyebabkan pertumbuhan ekonomi suatu wilayah meningkat yang berarti fundamental ekonomi daerah juga meningkat.

\section{Pembahasan}

Peran Wanita dalam Pembangunan. Peran wanita dalam pembangunan di kabupaten/kota di Jawa Tengah dilihat dari indikator tingkat pendidikan yang ditamatkan masih rendah sekali yaitu 68,63 persen pada tahun 2006. Pendidikan wanita di Provinsi Jawa Tengah, apabila dibandingkan dengan pendidikan penduduk lakilaki yang ditamatkan pada tahun 2006, untuk pendidikan rendah laki-laki 59,5 persen sedangkan wanita 66,5 persen. Untuk pendidikan menengah, laki-laki 36,2 persen wanita 29,9 persen, pendidikan wanita kategori pendidikan tinggi hanya 3,7 persen sedangkan laki-laki 4,4 persen. Hal ini menunjukkan bahwa pendidikan wanita di kabupaten/kota di Jawa Tengah masih lebih rendah dibandingkan laki-laki. Budaya Jawa yang masih kental dalam masyarakat di Jawa Tengah bahwa wanita tidak perlu pendidikan tinggi masih banyak terjadi di beberapa kabupaten/kota di Jawa Tengah terutama kabupaten/kota yang sebagian besar penduduknya mata pencahariannya pertanian. Sementara kabupaten/kota yang termasuk kota industri seperti kabupaten Cilacap, kabupaten Kudus, kabupaten Sukoharjo, kabupaten Semarang dan kota Semarang masih banyak penduduk wanitanya yang memilih kerja di perusahaan-perusahaan industri yang tidak memerlukan keahlian khusus atau pendidikan

Tabel 7. Hasil Uji Kausalitas Granger Variabel Pertumbuhan PDRB (growth ), Pendidikan yang Ditamatkan Wanita (Edu) dan Angkatan Kerja Wanita yang Bekerja (LF)

\begin{tabular}{lccc}
\hline $\begin{array}{l}\text { Pairwise Granger Causality Tests } \\
\text { Sample: } 20012009 \\
\text { Lags: } 2\end{array}$ & Obs & F-Statistic & \\
\hline Null Hypothesis: & 7 & 0,00417 & Prob. \\
GROWTH does not Granger Cause EDU & & 0,24242 & 0,9958 \\
EDU does not Granger Cause GROWTH & 7 & 0,33431 & 0,8049 \\
LF does not Granger Cause EDU & & 2,30872 & 0,7495 \\
EDU does not Granger Cause LF & 7 & 16,3524 & 0,3022 \\
LF does not Granger Cause GROWTH & & 3,04246 & 0,0576 \\
GROWTH does not Granger Cause LF & & & 0,2474 \\
\hline
\end{tabular}


tinggi seperti di perusahaan rokok, konveksi, makanan dan minuman.

Ditinjau dari aspek kesehatan, wanita di kabupaten/kota di provinsi Jawa Tengah belum memiliki tingkat kesadaran tentang kesehatan khususnya alat reproduksi wanita, hal ini bisa dilihat dari peserta keluarga berencana (KB) aktif rata-rata hanya 28,4 persen dari penduduk wanita usia produktif dan kawin. Rendahnya peserta KB yang tercatat karena sebagian wanita yang berpendidikan tinggi mengikuti KB mandiri dan sebagian lagi masih berprinsip banyak anak banyak rejeki terutama di kabupaten/kota yang di pedesaan. Dilihat dari peran wanita dalam sektor publik, sektor publik yang paling banyak menyerap perhatian wanita di jawa tengah adalah sektor pertanian sebesar 34 persen. Sektor pertanian umumnya tidak memerlukan persyaratan khusus (pendidikan formal) untuk memasukinya.

Dilihat dari potensi ketenagakerjaan, proporsi angkatan kerja yang bekerja termasuk tinggi, selama periode pengamatan sudah di atas 90 persen, namun apabila dibandingkan dengan angkatan kerja laki-laki yang bekerja, proporsi wanita masih dibawah laki-laki. Jumlah angkatan kerja wanita yang bekerja dengan status pekerjaan utama sebagai pekerja tak dibayar menempati porsi paling besar yaitu 27,8 persen. Besarnya pekerja yang tidak dibayar menunjukkan bahwa wanita di kabupaten/kota di Jawa Tengah masih lemah dalam hal bargaining power. Bekerja hanya sekedar membantu keluarga tanpa dibayar. Kondisi di atas menunjukkan bahwa peran wanita dalam pembangunan masih rendah.

Hasil penelitian ini tidak mendukung hasil penelitian Indrayati (2007) yang menghasilkan kesimpulan berdasarkan indikator pembangunan sektor wanita (lingkup nasional), peranan wanita dalam peran publik, pendidikan, kesehatan, dan ketengakerjaan adalah tinggi. Peran wanita dalam pembangunan di Jawa Tengah yang masih rendah ini sejalan dengan hasil penelitian dari Bappenas yang menyimpulkan bahwa disadari sudah banyak kemajuan yang dicapai dalam pembangunan pemberdayaan perempuan, yang antara lain ditandai dengan semakin meningkatnya status dan peran pe- rempuan di berbagai aspek kehidupan, tetapi bila dibandingkan dengan kemajuan laki-laki, status dan peran perempuan masih tertinggal (Bappenas, 2008). Peran yang masih rendah di berbagai aspek ini senada dengan hasil penelitian Azahari (2008) yang menyimpulkan bahwa tugas dan fungsi perempuan dalam kehidupan sosial memegang peranan penting, akan tetapi perempuan seringkali diabaikan dalam proses pembangunan terutama pembangunan pedesaan.

Hasil penelitian ini senada dengan laporan Bank Dunia (2009) yang menyimpulkan kualitas hidup perempuan Indonesia dengan memperhitungkan tingkat harapan hidup laki-laki dan perempuan; tingkat melek huruf orang dewasa laki-laki dan perempuan; rata-rata lama sekolah untuk laki-laki dan perempuan; dan perkiraan tingkat pendapatan laki-laki dan perempuan, masih tertinggal jauh dibandingkan negara-negara sesama ASEAN seperti Malaysia, Thailand dan Fhilipina. Tepatnya, dalam Human Development Report (HDR) 2007/ 2008, pada tahun 2006 posisi GDI Indonesia ada di peringkat 81 di atas Vietnam (82) namun di bawah Malaysia (51), Thailand (58) dan Filipina 66. Dari sisi peringkat GDI Indonesia memang meningkat sejak HDR 2002 hingga HDR 2006. Akan tetapi peningkatan tersebut masih belum mampu menggeser perbandingan angka HDI dengan Gender Related Development Index (GDI). Ketika angka HDI lebih tinggi dibandingkan GDI, menunjukkan keberhasilan pembangunan manusia secara keseluruhan belum sepenuhnya diikuti dengan keberhasilan meningkatkan kualitas hidup perempuan atau masih terjadi ketimpangan gender.

\section{Hubungan Kausalitas Fundamental Ekonomi Daerah dan Peran Wanita dalam Pembangun-} an. Pengujian hubungan kausalitas antara fundamental ekonomi daerah dengan indikator pertumbuhan PDRB dan peran wanita dalam pembangunan diwakili dua indikator yaitu tingkat pendidikan yang ditamatkan wanita dan banyaknya angkatan kerja wanita yang bekerja. Uji hubungan kausalitas dengan menggunakan uji kausalitas Granger adalah menguji hubungan kausalitas dalam konteks jangka 
pendek. Hasil penelitian menunjukkan bahwa tidak terdapat pola hubungan kausal antara fundamental ekonomi daerah dan peran wanita dalam pembangunan khususnya pendidikan yang ditamatkan dan sebaliknya. Namun dalam penelitian ditemukan hubungan kausal antara peran wanita dalam pembangunan, khususnya banyaknya angkatan kerja wanita yang bekerja dengan fundamental ekonomi daerah. Semakin banyak angkatan kerja wanita yang bekerja yang berarti peran wanita dalam pembangunan meningkat, menyebabkan semakin tinggi pertumbuhan PDRB yang berarti fundamental ekonomi daerah meningkat.

Hasil penelitian ini konsisten dengan penelitian Fadilah (2010) yang menyimpulkan ada pergeseran peran wanita sebagai peran ekonomi. Secara ekonomi dulu wanita hanya dianggap sebagai tulang rusuk bagi suami dalam rumah tangga yaitu peran sebagai pendamping, teman, mitra, dan bahkan ada anggapan minor yang menumpang hidup kepada suaminya, kini bergeser menyandang peran sebagai tulang punggung (pencari nafkah) bagi keluarganya. Hasil studi dari Fadilah jika diterapkan dalam lingkungan yang lebih luas tidak hanya sebatas keluarga tetapi wilayah regional akan menghasilkan kesimpulan yang sama yaitu semakin tinggi peran wanita maka fundamental ekonomi daerah akan semakin meningkat.

Peran wanita dalam pembangunan yang meningkat akan menyebabkan fundamental ekonomi daerah yang meningkat senada dengan hasil penelitian Ismail (1995). Hasil studinya menghasilkan kesimpulan yang senada bahwa meningkatnya produktivitas tenaga kerja wanita di bidang pertanian menyebabkan meningkatkan pembangunan pertanian di Malaysia. Pembangunan manusia mempunyai pengaruh tidak langsung terhadap pertumbuhan melalui konsolidasi demokrasi. Pada umumnya wanita yang bekerja mempunyai bargaining power dan partisipasi yang semakin tinggi. Tingkat melek huruf yang tinggi, kesehatan yang baik, dan kesamaan kesempatan memungkinkan partisipasi masyarakat dalam proses politik dan membantu membangun konsensus atas tujuan pembangunan. Demokrasi yang partisipasif merupakan alat yang efektif bagi pengumpulan suara dan resolusi konflik yang pada gilirannya meningkatkan stabilitas politik dan sosial. Pembangunan yang memberdayakan masyarakat atau peran serta dan inisiatif lokal menyebabkan efisiensi pilihan investasi dan penyediaan jasa meningkat.

Hasil penelitian ini juga senada dengan hasil studi Wulandari dkk (2006) yang menyimpulkan sebesar 96,9 persen dari sampel yang diambil wanita memiliki kesadaran yang tinggi untuk ikut serta dalam mengatasi pengangguran dengan cara menciptakan lapangan kerja baru yaitu mengelola usaha kecil menengah dan koperasi. Wanita pelaku usaha ini berarti memiliki peran ekonomi. Peran ekonomi yang semakin tinggi akan meningkatkan fundamental ekonomi daerah.

\section{SIMPULAN}

Berdasarkan hasil penelitian dan pembahasan dapat disimpulkan sebagai berikut: Peran wanita dalam pembangunan di kabupaten/kota di Provinsi Jawa Tengah masih rendah, dilihat dari aspek pendidikan, kesehatan, peran wanita di sektor publik dan potensi ketenagakerjaannya, terdapat hubungan searah antara peran wanita dalam pembangunan dengan fundamental ekonomi daerah, artinya peran wanita dalam pembangunan yang meningkat, menyebabkan fundamental ekonomi daerah meningkat. Namun tidak terdapat hubungan yang timbal balik antara keduanya dalam studi ini.

Adapun saran dalam penelitian ini adalah: perlu peningkatan peran wanita dengan memberikan kesempatan lebih luas wanita memperoleh pendidikan tinggi, pelayanan umum dan informasi kesehatan wanita, penyediaan lapangan kerja wanita di sektor publik. Uji Kausalitas Granger hanya digunakan sebagai analisis jangka pendek, untuk keperluan arah kebijakan perlu menguji hubungan antara fundamental ekonomi daerah dan peran wanita dalam pembangunan jangka panjang, dengan alat analisis lainnya seperti uji kausalitas model koreksi kesalahan baku, yang tidak memerlukan persyaratan data stasioner bagi data times series 


\section{DAFTAR PUSTAKA}

Azahari, D.H. 2008. Indonesian Rural Women: the Role in Agricultural Development. Analisis Kebijakan Pertanian, Vol.6 No.1 hal 1-10.

Bank Dunia. 2009. Gender Related Development Index.(online). http://hdr.undp.org/en/ media/HDR_20072008_GDI.pdf, diakses 21 Agustus 2010

Bank Pembangunan Asia, 2007, Kebijakan ADB Mengenai Gender dan Pembangunan. (online). http://www.adb.org/documents/ translation/indonesian/kebijakan_gender _id.pdf, diakses tanggal 19 Maret 2010.

Bappenas. 2008. Peningkatan Kualitas Kehidupan dan Peran Perempuan Serta Kesejahteraan dan Perlindungan Anak. http://www. bappenas.go.id, diakses pada tanggal 27 Mei 2009

Barro. 1991. Economic Growth in a Cross Section of Countries, Quartely Journal of Economics, Vol 106, No.2, pp 407-443.

Bhalla, S. 1994. Freedom and Economic Growth: A Virtuous Circle, Nobel Symposium Democracy's Victory and Crisis, Uppsala University.

Biro Pusat Statistik. 2008. Jawa Tengah Dalam Angka Tahun 2000-2007. Jakarta: BPS

Biro Pusat Statistik. 2008. Statistik Sosial dan Kependudukan Jawa Tengah Hasil Susenas Tahun 2001-2007. Jakarta: BPS.

Fadilah, S. 2010. Kesetaraan Gender: Fenomena Pergeseran Peran Ekonomi Wanita dari Tulang Rusuk menjadi Tulang Punggung, Jurnal Kajian Gender (JKG), Vol.1 No.1, hal 159-169.

Indrayati, Ariyani, dkk. 2007. Dinamika Alokasi Pembiayaan Pembangunan Sektor Peranan
Wanita di Indonesia Tahun 1980-2005, Penelitian DP2M.

Ismail, M. 1995. Roles of Progressive Malaysian Farmer in Rural Development: A Gender Analysis. Pertanika Journal of Social, Science $\mathcal{E}$ Human, Vol 3 No.1 pp 11-19.

Kementerian PP \& PA bekerjasama BPS. 2009. Pembangunan Berbasis Gender 2006, 2007, dan 2008. (online). http://www.sumbar prov.go.id/images/media/GDI.pdf, diakses tanggal 21 Agustus 2010.

Kuncoro, M. 2003. Metode Riset untuk Bisnis $\mathcal{E}$ Ekonomi: Bagaimana Meneliti \& Menulis Tesis ?. Jakarta: Erlangga.

Kuncoro, M. 2001. Metode Kuantitatif: Teori dan Aplikasi untuk Bisnis dan Ekonomi. Yogyakarta: UPP AMP YKPN.

Kuncoro, M. 2004. Otonomi dan Pembangunan Daerah: Reformasi, Perencanaan, Strategi, dan Peluang. Jakarta: Erlangga.

Setyasih, Endang Tri. 2006. Konsep Diri dan Peranan Wanita dalam Pembangunan. Jurnal Visioner Vol.2 No.1 hal 136-146.

Todaro, Michael P. 2006. Pembangunan Ekonomi di Dunia Ketiga. Jakarta: Erlangga

UNSFIRS. 2000. Indonesia: The National Human Development Report. Jakarta: United Nations Support Facility for Indonesian Recovery (UNSFIRS) and UNDP.

Vantina, dkk. 2008. Keadilan Gender dalam Pengambilan Kebijakan: Antara Harapan dan Kenyataan (Studi Kasus Pada Sekretariat Daerah Kota Samarinda Tahun 2008). Jurnal Sosial-Politika, Vol.15, No.1.

Wulandari, dkk. 2006. Studi Peran Serta Wanita dalam Pengembangan Usaha Kecil Menengah dan Koperasi. Jurnal Pengkajian Koperasi dan UKM, No .1 Tahun 1. 